\title{
PROPOSAL PENELITIAN
}

PENERAPAN KETERAMPILAN MENULIS TEKS PROSEDUR KOMPLEKS MELALUI MODEL PEMBELAJARAN STAD (STUDENT TEAM ACHIEVEMENT DIVISION) PADA SISWA KELAS X SMAN 1 NAN SABARIS

Tugas Mata Kuliah Metode Penelitian Pembelajaran Bahasa Indonesia yang Dibina Oleh Prof. Dr. Syahrul R, M.Pd.

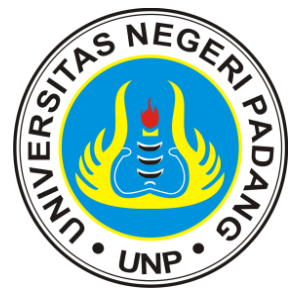

SILVINA ROSA OKTAVIANI

$19016052 / 2019$

PROGRAM STUDI PENDIDIKAN BAHASA INDONESIA

JURUSAN BAHASA DAN SASTRA INDONESIA DAN DAERAH

FAKULTAS BAHASA DAN SENI

UNIVERSITAS NEGERI PADANG

2021 


\section{DAFTAR ISI}

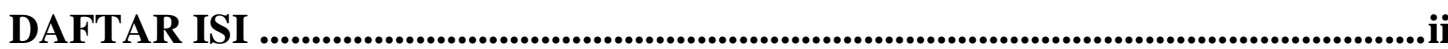

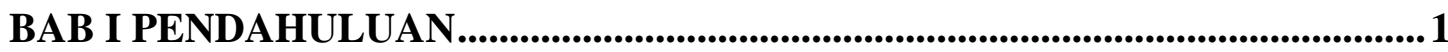

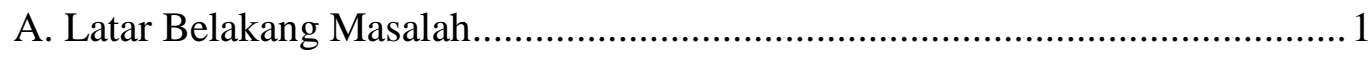

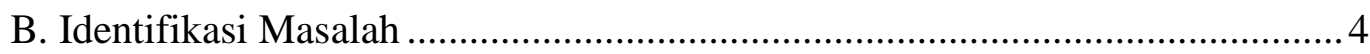

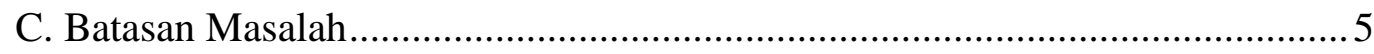

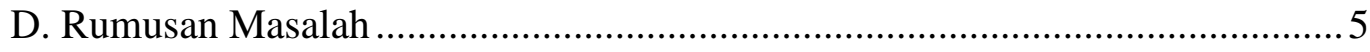

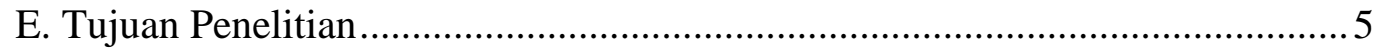

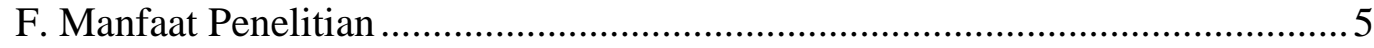

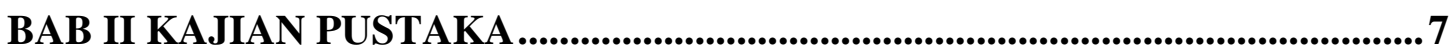

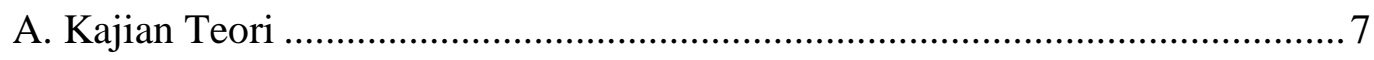

1. Keterampilan Menulis Teks Prosedur Kompleks .................................. 7

2. Model Pembelajaran STAD (Student Team Achievement Division) ........ 10

3. Pemahaman Konsep ........................................................................ 13

4. Penerapan Keterampilan Menulis Teks Prosedur Kompleks Melalui Model Pembelajaran STAD (Student Team Achievement Division) ..................... 16

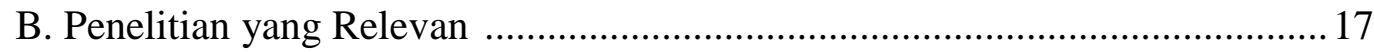

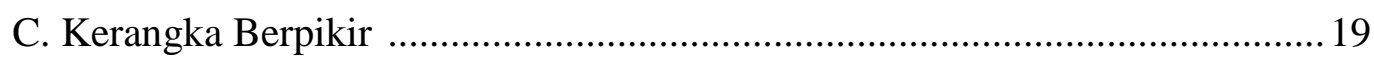

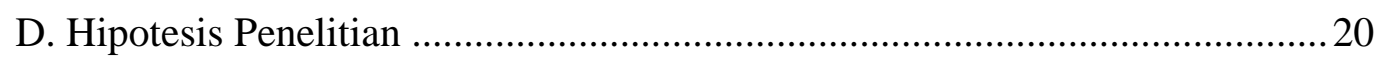

BAB III METODOLOGI PENELITIAN.. ......................................................21

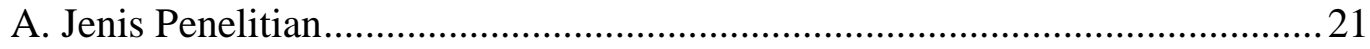

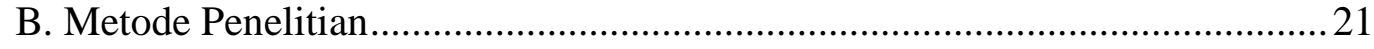

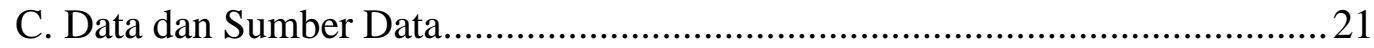

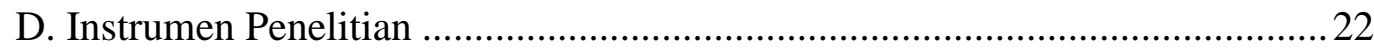

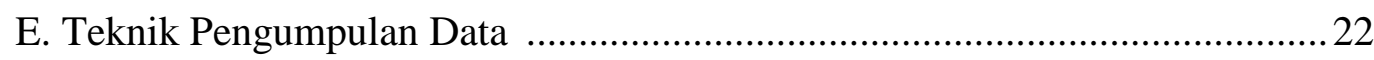

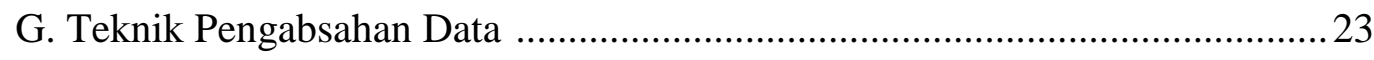

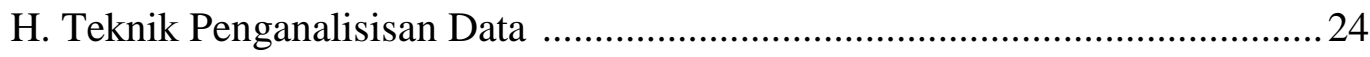

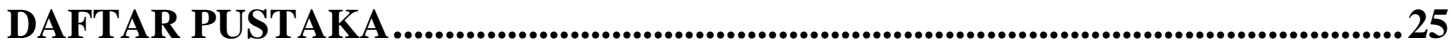




\section{BAB I \\ PENDAHULUAN}

\section{A. Latar Belakang Masalah}

Keterampilan berbahasa pada kurikulum tingkat menengah atas meliputi empat keterampilan yakni keterampilan menyimak, berbicara, membaca, dan menulis. Keempat aspek ini terintegrasi dalam pencapaian tujuan pembelajaran yang diselenggarakan di sekolah. Seperti yang diungkap oleh Tarigan (Rojaki, 2012:59) bahwa keterampilan berbahasa (language Skill) dalam kurikulum sekolah mencakup empat segi keterampilan yaitu menyimak (listening), berbicara \{speaking), membaca (reading), dan menulis (writing). Keterampilan menulis dalam pembelajaran adalah suatu hal yang penting. Dalam kegiatan menulis ini, penulis harus terampil memanfaatkan grafologi, struktur bahasa dan kosa kata.

Selain itu, keterampilan menulis ini tidak akan datang secara otomatis, tetapi harus melalui latihan dan praktik yang banyak dan teratur. Menulis merupakan kegiatan menuangkan pikiran, ide, dan perasaan kepada orang lain melalui bahasa tulis. Namun, dalam menulis, penulis cenderung mengalami kesulitan menuangkan gagasan atau idenya (Sari et al., 2018). Di Indonesia, faktor khusus yang menyebabkan kesulitan dalam menulis adalah bahasa daerah (Valiantien et al., 2016).

Hal ini mengakibatkan tulisan yang dihasilkan siswa cenderung membawa pengaruh bahasa daerah mereka. Bahkan dapat ditemui sebagian siswa kerap mengalami kebingungan dalam menerjemahkan bahasa daerahnya ke bahasa Indonesia. Hal tersebut terjadi karena faktor kosakata dan kesulitan memilih kosakata yang efektif (Rakafaeri et al., 2020). Kesulitan yang dialami penulis tersebut disebabkan oleh beberapa faktor.

Faktor yang memengaruhi keterampilan menulis dapat berupa faktor internal dan eksternal (Novariana et al., 2018). Keterampilan menulis adalah kemampuan menuangkan buah pikiran ke dalam bahasa tulis melalui kalimat-kalimat yang dirangkai secara utuh, lengkap, dan jelas sehingga buah pikiran tersebut dapat dikomunikasikan kepada pembaca dengan berhasil Byrne (Mardiyah, 2016:3). Penulis biasanya lebih memikirkan apa yang dikomunikasikan. Namun demikian, penulis tetap harus melibatkan perhatian pembaca. Menulis merupakan salah satu aspek keterampilan berbahasa yang sangat rumit. Dikatakan 
rumit, sebab menulis merupakan muara dari keterampilan berbahasa yang lain dan masih perlu didukung oleh pengetahuan kebahasaan yang memadai.

Seseorang akan mahir dalam menulis apabila sudah berkemampuan menguasai keterampilan menyimak, berbicara, membaca, dan menulis. Menulis memiliki peranan penting pada pembelajaran bahasa Indonesia. Namun, pada kenyataannya saat penulis melakukan observasi disekolah banyak anak-anak yang lebih memilih bermain saat diminta untuk menulis pada saat proses pembelajaran tersebut. Sehingga anak tersebut tidak tahu apa yang harus dikerjakan.

Hal tersebut dikarenakan banyak berbagai faktor didalamnya, diantaranya Kurangnya guru dalam mengajar menggunakan metode dalam mengajar, dan banyak ceramah. Dalam mengatasi minat anak yang kurang mau menulis dapat dilakukan dengan beberapa cara, seperti memberikan motivasi terhadap anak tersebut atau memilih model pembelajaran yang menarik. Salah satu model pembelajaran yang dapat digunakan adalah model Student Team Achievement Division (STAD). Menurut Slavin (Prihaniwati et al., 2018), tipe STAD merupakan salah satu metode pembelajaran kooperatif yang paling sederhana dan merupakan model yang paling baik untuk pemulaan bagi para guru yang baru menggunakan pendekatan kooperatif.

Model pembelajaran kooperatif tipe Student Team Achievement Division (STAD) merupakan model pembelajaran yang dapat membantu siswa menjadi lebih antusias dan bertanggung jawab dalam belajar sehingga membantu siswa menyerap materi dengan lebih baik (Sri et al., 2020). Pembelajaran model STAD dapat meningkatkan hasil belajar, hubungan antar kelompok, memberi kesempatan kepada siswa berinteraksi dan beradaptasi dengan teman satu tim untuk mencerna materi pelajaran, meningkatkan rasa percaya diri dan motivasi belajar, membina sifat kebersamaan, peduli satu sama lain, dan tenggang rasa, serta mempunyai rasa adil terhadap keberhasilan tim. Penelitian di Yordania (Rababah et al., 2013), menunjukkan bahwa hal yang paling berpengaruh dalam keterampilan menulis adalah kreativitas. Penelitian tersebut menunjukkan bahwa keterampilan menulis perlu dikaji dari segala aspek, sehingga kesulitan yang akan dihadapi dapat ditanggulangi.

Mengenai menulis suatu teks, STAD merupakan salah satu metode atau pendekatan dalam pembelajaran kooperatif yang sederhana dan ini sangat bagus digunakan oleh guru yang baru mulai menggunakan pendekatan kooperatif di dalam kelas. STAD juga merupakan 
suatu pembelajaran yang efektif. STAD mempunyai lima komponen utama yaitu penyajian materi, kelompok, kuis, pemberian skor, hadiah untuk tiap kelompok (Yuniar, 2018).

STAD (Student Team Achievement Division) merupakan model pembelajaran yang sangat menarik, dimana di dalam proses pembelajaran siswa akan dibagi perkelompok. Model pembelajaran STAD ini sangat bagus diterapkan dalam pembelajaran teks prosedur kompleks, karena masih banyak tenaga pendidik mengajar khususnya mengenai teks prosedur kompleks dengan menggunakan metode ceramah, hal ini dapat membosankan siswa-siswi dalam belajar, dan hal ini dapat menjenuhkan pikiran siswa-siswi disaat belajar. Maka dari itu, digunakanlah model belajar STAD ini agar siswa-siswi dapat berdiskusi dan bertukar pendapat.

Teks prosedur kompleks merupakan suatu langkah-langkah dan tujuan yang harus diikuti agar suatu pekerjaan dapat dilakukan. Teks prosedur kompleks memiliki manfaat yang besar dalam kehidupan. Teks prosedur kompleks membantu mengetahui cara-cara melakukan aktivitas tertentu dan kebiasaan hidup yang benar peduli.

Untuk mencapai tujuan yang tepat teks prosedur harus disusun sesuai dengan urutan yang benar. Karena langkah-langkah dalam menyusun teks prosedur tidak dapat dibalik-balik untuk mencapai tujuan tersebut (Siti et al., 2016). Adanya kondisi realitas siswa yang cenderung kurang memperhatikan guru ketika mengajar juga menjadi penyebab tidak tercapainya materi menulis teks prosedur kompleks. Siswa terlihat berbicara dengan temannya ketika pelajaran.

Hal itu menyebabkan siswa tidak terfokus pada pembelajaran yang dilakukan. Bahkan, ada beberapa siswa yang masih senang bermain gadgetnya selama proses pembelajaran. Selain itu, kurangnya kemampuan siswa menulis teks prosedur kompleks juga disebabkan oleh media yang digunakan guru dalam proses pembelajaran. Guru masih menggunakan media papan tulis untuk menyampaikan materi teks prosedur kompleks pada siswa, walaupun sudah disediakan LCD dan projektor (Winarsih et al., 2015).

Trianto (Ramafrizal 2018) menyatakan bahwa pembelajaran kooperatif tipe STAD ini merupakan salah satu tipe dari model pembelajaran kooperatif dengan menggunakan kelompok-kelompok kecil dengan jumlah anggota tiap kelompok 4-5 orang siswa secara heterogen. Ada beberapa kendala yang membuat siswa kurang mampu menulis teks prosedur sesuai dengan yang diharapkan. Kendala guru yang seharusnya sebagai fasilitator di dalam ruang kelas masih memakai metode ceramah membuat siswa yang mendengarkan merasa 
bosan. Di samping itu juga, guru menggunakan sistem belajar klasikal atau sistem belajar individual.

Membuat siswa kurang efektif dalam menuangkan ide. Situasi tersebut menuntut guru untuk mencari model pembelajaran yang tepat, guna merangsang dan meningkatkan keterampilan siswa dalam menulis teks prosedur. Hal ini sesuai dengan yang dikemukakan oleh Nurhayati (Septia 2020) "Salah satu upaya yang dapat dilakukan dengan menggunakan model pembelajaran yang tepat. Oleh karena itu, guru dituntut untuk dapat merancang, menyusun, menggunakan pendekatan yang tepat untuk tiap-tiap materi pelajaran sehingga guru dapat menjalankan tugasnya dengan efektif, efisien, dan anak didik dapat memiliki pemahaman yang tuntas dan bermakna terhadap materi pembelajaran yang disajikan sehingga dapat meningkatkan kemampuan profesionalnya".

Upaya mengatasi permasalahan di atas adalah dengan cara mengubah model pembelajaran. Model yang digunakan adalah model pembelajaran kooperatif tipe Student Team Achievement Division (STAD). Model pembelajaran kooperatif tipe STAD mengharuskan siswa untuk bekerja sama dan saling bergantung secara positif antar satu sama lain dalam konteks struktur tugas, struktur tujuan. Dari pengertian di atas dapat dinyatakan bahwa model pembelajaran kooperatif tipe STAD merupakan suatu model pembelajaran kooperatif yang diterapkan dalam proses pembelajaran di kelas, pembelajaran menggunakan kelompok-kelompok dengan jumlah anggota kelompok 4-5 orang siswa secara heterogen.

Model STAD lebih mementingkan sikap partisipasi peserta didik dalam rangka mengembangkan potensi kognitif dan afektif kelebihan STAD ini, maka dari itu model pembelajaran STAD ini sangat bagus digunakan pada pembelajaran teks prosedur kompleks. Keunggulan pembelajaran kooperatif tipe STAD terletak pada langkah-langkah pembelajaran yang diterapkan. Penerapan model pembelajaran kooperatif tipe STAD diharapkan mampu meningkatkan hasil belajar siswa. Keunggulan pembelajaran kooperatif tipe STAD yaitu siswa bekerja dalam kelompok sehingga siswa dapat memahami. konsep materi yang ada dengan bantuan teman kelompok mereka (Ika et al., 2017).

\section{B. Identifikasi Masalah}

Berdasarkan uraian yang telah dikemukakan dalam latar belakang masalah diatas, maka identifikasi masalah dalam penelitian ini adalah sebagai berikut. Pertama, rendahnya keterampilan menulis teks prosedur kompleks siswa disebabkan oleh faktor kosakata. Kedua, siswa merasa bosan dan tidak cepat mengerti jika guru menggunakan metode pembelajaran 
ceramah, maka dari itu metode pembelajaran tersebut diubah menjadi metode pembelajaran STAD. Ketiga, siswa belum mampu menulis dan memahami teks prosedur kompleks sesuai dengan tema.

\section{Batasan Masalah}

Berdasarkan identifikasi masalah tersebut, permasalahan penelitian ini dibatasi pada penerapan keterampilan menulis tek prosedur kompleks melalui model pembelajaran STAD (Student Team Achievement Division) pada siswa kelas X SMAN 1 Nan Sabaris.

\section{Rumusan Masalah}

Rumusan masalah dalam penelitian ini adalah sebagai berikut. Pertama, bagaimanakah cara guru dalam menerapkan keterampilan menulis teks prosedur kompleks melalui model pembelajaran STAD pada siswa kelas X SMAN 1 Nan Sabaris?. Kedua, apakah penggunaan model pembelajaran STAD berdampak baik terhadap hasil pembelajaran menulis teks prosedur kompleks pada siswa kelas X SMAN 1 Nan Sabaris?.

\section{E. Tujuan Penelitian}

Berdasarkan rumusan masalah di atas, tujuan penelitian ini adalah sebagai berikut. Pertama, mendeskripsikan cara guru dalam menerapkan keterampilan menulis teks prosedur kompleks melalui model pembelajaran STAD pada siswa kelas X SMAN 1 Nan Sabaris. Kedua, mendeskripsikan apakah penggunaan model pembelajaran STAD berdampak baik terhadap hasil pembelajaran menulis teks prosedur kompleks pada siswa kelas X SMAN 1 Nan Sabaris.

\section{F. Manfaat Penelitian}

Penelitian ini memiliki dua manfaat, yaitu manfaat teoretis dan manfaat praktis. Secara teoretis, penelitian ini diharapkan bermanfaat untuk menambah dan memperkaya teori ilmu pengetahuan dalam bidang menulis teks prosedur kompleks. Secara praktis, hasil penelitian ini diharapkan dapat memberikan manfaat kepada pihak-pihak berikut. Pertama, bagi guru, khususnya guru bahasa Indonesia di SMAN 1 Nan Sabaris, yaitu sebagai bahan masukan dalam meningkatkan hasil belajar teks prosedur kompleks. Kedua, bagi siswa SMAN 1 Nan Sabaris, yaitu sebagai umpan balik yang berguna untuk memotivasi diri dan selalu meningkatkan kemampuan dalam pelajaran bahasa Indonesia. Ketiga, bagi pembaca, hasil 
penelitian ini diharapkan dapat menambah konsep maupun teori tentang teks prosedur kompleks. 


\section{BAB II \\ KAJIAN PUSTAKA}

\section{A. Kajian Teori}

Berdasarkan permasalahan penelitian, terdapat tiga teori yang akan diuraikan pada kajian teori ini. Pertama, keterampilan menulis teks prosedur kompleks. Kedua, model pembelajaran STAD (Student Team Achievement Division). Ketiga, penerapan keterampilan menulis teks prosedur kompleks melalui model pembelajaran STAD (Student Team Achievement Division).

\section{Keterampilan Menulis Teks Prosedur Kompleks}

Teori yang akan diuraikan dalam keterampilan menulis teks prosedur kompleks, yaitu (a) pengertian menulis, (b) pengertian teks prosedur kompleks, (c) struktur teks prosedur kompleks, (d) kaidah kebahasaan teks prosedur kompleks, dan (e) penilaian dalam menulis teks prosedur kompleks.

\section{a. Pengertian Menulis}

Keterampilan berbahasa dengan komunikasi tidak tatap muka, tetapi bersifat produktif adalah menulis (Tarigan, 2015). Menulis merupakan sarana untuk menuangkan pikiran, gagasan, dan perasaan seseorang dengan harapan dapat dipahami oleh pembaca (Rosidi, 2009). Sementara itu, Semi (Sardila, 2015) mengemukakan bahwa menulis adalah suatu metode kreatif mentransfer gagasan ke dalam lambang-lambang tulisan. Hidayati (2009: 90) memberikan pendapat bahwa menulis merupakan kegiatan pengungkapan ide, gagasan, perasaan, atau emosi ke dalam bentuk tulisan.

Kegiatan ini memerlukan beberapa keahlian, baik dari segi kebahasaan maupun segi pemikiran sang penulis.Menulis merupakan salah satu aspek keterampilan berbahasa yang sangatrumit. Dikatakan rumit, sebab menulis merupakan muara dari keterampilan berbahasa yang lain dan masih perlu didukung oleh pengetahuan kebahasaan yang memadai. Hal ini senada dengan pendapat Bell dan Burnaby (Mardiyah, 2016:57) bahwa menulis merupakan aktivitas kognitif yang kompleks, sebab pada waktu yang bersamaan penulis harus mengatur sejumlah variabel.

Variabel dalam tingkat kalimat terdiri dari pengaturan isi, susunan, strukturkalimat, kosa kata, tanda baca, dan ejaan, sedangkan variabel di luar kalimat adalah penyusunan dan penggabungan kalimat menjadi sebuah paragaraf. Menulis, menurut Crimmon (Mardiyah, 2016:2) menulis merupakan kegiatan menggali pikiran dan perasaan mengenai suatu subjek, 
memilih hal-hal yang akan ditulis, menentukan cara menuliskannya sehingga pembaca dapat memahaminya dengan mudah dan jelas. Sejalan dengan pendapat di atas,Slamet (Mardiyah, 2016:96) berpendapat bahwa menulis itu bukan hanya berupa melahirkan pikiran atau perasaan saja, melainkan juga merupakan pengungkapan ide, pengetahuan, ilmu, dan pengalaman hidup seseorang dalam bahasa tulis.

Berdasarkan definisi tersebut, dapat disimpulkan bahwa menulis merupakan salah satu alat komunikasi secara tidak langsung untuk menuangkan ide, pandangan, dan perasaan. Melalui menulis, seseorang dapat menyampaikan ide, pandangan dan perasaannya untuk dipahami oleh pembaca.

\section{b. Pengertian Teks Prosedur Kompleks}

Teks Prosedur Kompleks adalah teks yang berisi langkah-langkah yang harus ditempuh untuk mencapai tujuan yang diinginkan dan terdapat penjelasan/keterangan dalam langkah tersebut. Dibawah ini ada beberapa pengertian teks prosedur kompleks menurut beberapa ahli. Kosasih (Anis 2015:131) mengatakan bahwa teks prosedur kompleks adalah teks yang yang menjelaskan langkah-langkah secara lengkap dan jelas tentang cara melakukan sesuatu. Selain itu, dalam buku wajib Bahasa Indonesia kelas X SMA dideskripsikan bahwa teks prosedurkompleks berisi langkah-langkah atau tahap yang harus ditempuh untuk mencapai tujuan. Kemendikbud (2014:36) menjelaskan "Teks prosedur adalah teks yang berisikan langkah-langkah atau tahap yang harus ditempuh untuk mencapai tujuan".

\section{c. Struktur Teks Prosedur Kompleks}

Teks prosedur kompleks memiliki dua struktur. Struktur pertama merupakan pendahuluan. Pendahuluan berisi pengantar yang berkaitan dengan petunjuk yang akan dikemukakan pada bagian pembahasan. Struktur yang kedua merupakan pembahasan. Pembahasan berisi petunjuk atau langkah-langkah pengerjaan sesuatu yang disusun secara sistematis. Penyusunannya menngikuti urutan waktu atau bersifat kronologis. Dalam teks prosedur kompleks terdapat struktur yang membentuk teks tersebut. Seperti halnya teks lain yang terbentuk sesuai struktur yang telah di- tetapkan. Menurut Kosasih (2014:68) terdapat struktur teks prosedur kompleks yang meliputi: (1) Tujuan, berisi pengantar berkaitan dengan petunjuk yang akan dikemukakan pada bagian pembahasan,(2) Langkah-langkah, pembahasan diisi dengan petunjuk pengerjaan sesuatu yang disusun secara sistematis, dan (3) Penutup, diisi dengan kalimat-kalimat yang seperlunya, tidak berupa kesimpulan.

Struktur teks prosedur kompleks yang disampaikan oleh para ahli diatas dapat penulis simpulkan bahwa struktur teks prosedur kompleks dapat dibagi menjadi tiga bagian. Struktur 
pertama meliputi tujuan. Struktur kedua yakni struktur langkah-langkah. Di dalam struktur kedua menjadi inti kegiatan dari teks prosedur kompleks. Struktur terakhir yakni penutup, di dalam penutup terdapat kalimat yang menutup langkah-langkah prosedur kompleks.

\section{d. Kaidah Kebahasaan Teks Prosedur Kompleks}

Kosasih (2014: 71) beberapa kaidah yang berlaku pada teks prosedur kompleks adalah sebagai berikut:

a) Karena merupakan petunjuk, teks prosedur kompleks banyak meng-gunakan kalimat perintah (command).

b) Konsekuensi dari penggunaan dalam perintah, banyak pula pemakaian kata kerja imperatif, yakni kata yang menyatakan perintah, keharusan, atau larangan. Contoh: buatlah, cipatakan, aturlah, carilah, harus, jangan, perlu, tak perlu.

c) Dalam teks prosedur kompleks juga banyak digunakan konjungsi temporal atau kata penghubung yang menyatakan urutan waktu kegiatan, seperti, dan, lalu, kemudian, setelah itu, selanjutnya. Kata-kata tersebut hadir sebagai konsekuensi dari langkahlangkah penggunaan sesuatu yang bersifat kronologis. Akibatnya, teks semacam itu menuntut kehadiran konjungsi yang bermakna kronologis pula.

d) Dalam teks yang sejenis, banyak pula digunakan kata-kata penunjuk waktu, seperti beberapa menit kemudian, setengah jam. Kata-kata itu terutama banyak digunakan dalam resep makanan.

e) Kadang-kadang menggunakan kata-kata yang menyatakan urutan langkah kegiatan, seperti pertama, kedua, ketiga dan seterusnya.

f) Banyak menggunakan keterangan cara, misalnya dengan cepat, dengan lembut, dengan perlahan-lahan.

g) Banyak menggunakan kata-kata teknis, sesuai dengan temanya. Misalnya, petunjuk berlalu lintas, lebih banyak menggunakan kata-kata seperti SIM.

h) Dalam petunjuk yang berupa resep, dikemukakan pula gambaran rinci tentang nama benda yang dipakai, termasuk jumlah, urutan, ataupun bentuknya.

Berdasarkan uraian di atas dapat disimpulkan bahwa kaidah kebahasaan teks prosedur kompleks menurut Kosasih terdiri dari delapan bagian. Bentuk teks prosedur kompleks merupakan teks yang menjelaskan cara-cara melakukan sesuatu yang di dalamnya terdapat ciri kebahasaan yang paling menonjol yaitu kalimat perintah dan konjungsi termporal yang digunakan di dalamnya, namun bukan berarti kaidah kebahasaan yang lain tidak digunakan.

\section{e. Penilaian Dalam Menulis Teks Prosedur Kompleks}

Untuk menentukan kebenaran ketepatan menulis teks prosedur kompleks yang dibuat oleh siswa, dibutuhkan sebuah penilaian untuk menentukan sejauh mana pemahaman siswa 
terhadap materi pembelajaran yang diberikan. Penilaian sangat diperlukan untuk akhir proses pembelajaran, maka aspek yang perlu dinilai menurut Mahsun (2014:162) adalah sebagai berikut:

a) Ketepatan dalam penetapan dan cara penggunaanbahan/alat.

b) Ketepatan pengelompokan data berdasarkan strukturteks.

c) Ketepatan pengolahan data menjadikalimat.

d) Ketepatan pengolahan kalimat menjadiparagraf.

e) Ketepatan penggunaan penghubung antarparagraf.

f) Ketepatan penggunaanejaan.

Aspek-aspek penilaian menurut Mahsun ini akan penulis jadikan sebagai acuan saat penulis melakukan penilaian. Dalam melakukan penilaian tingkat keberhasilan dinilai berdasarkan skor.

a) Skor 4 (baik sekali) tanpa atau hampir tanpa adakesalahan

b) Skor 3 (baik) jumlah unsur benar lebih tinggi daripada unsursalah

c) Skor 2 (sedang) unsur yang benar dengan unsur yang salahberimbang

d) Skor 1 (kurang) tidak ada unsur yang benar atau unsur yang salah

lebih besar daripada unsur benar (Mahsun 2014:161)

Skor penelitian inilah yang penulis jadikan acuan saat mengukur tingkat keberhasilan pada penilaian lembar jawaban siswa dalam penelitian.

\section{Model Pembelajaran STAD (Student Team Achievement Division) \\ a. Pengertian STAD (Student Team Achievement Division)}

Student Teams Achievement Divisions (STAD) merupakan salah satu metode pembelajaran kooperatif yang paling sederhana, dan merupakan model yangpaling baik untuk permulaan bagi para guru yang baru menggunakan model kooperatif (Robert E. Salvin,2005:143). Student Teams Achievement Divisions (STAD) cenderung pembelajaran dengan belajar kelompok, dimana siswa dalam kelompoknya yang mengalami kesulitan akan dibantu oleh siswa yang lain dalam kelompoknya. Isjoni (2011:74) mengatakan, "Tipe STAD merupakan salah satu tipe kooperatif yang menekankan pada adanya aktivitas dan interaksi diantara siswa untuk saling memotivasi dan salingmembantu dalam menguasai materi pelajaran gunamencapai prestasi yang maksimal". Trianto (Ramafrizal, 2018) menyatakan bahwa pembelajaran kooperatif tipe STAD ini merupakan salah satu tipe dari model pembelajaran kooperatif dengan menggunakan kelompok-kelompok kecil dengan jumlah anggota tiap kelompok 4-5 orang siswa secara heterogen. Ada beberapa kendala yang membuat siswa kurang mampu menulis teks prosedur sesuai dengan yang diharapkan. 


\section{b. Keunggulan STAD (Student Team Achievement Division)}

Keunggulan pembelajaran koopertatif tipe STAD terletak pada langkah-langkah pembelajaran yang diterapkan. Penerapan model pembelajaran kooperatif tipe STAD diharapkan mampu meningkatkan hasil belajar siswa. Keunggulan pembelajaran kooperatif tipe STAD yaitu siswa bekerja dalam kelompok sehingga siswa dapat memahami konsep materi yang ada dengan bantuan teman kelompok mereka. Hal ini diperkuat dalam hasil penelitian Asdar (Ika et al., 2009) pembelajaran kooperatif tipe STAD, bekerja dalam kelompok sehingga siswa dapat menumbuhkan kemauan kerja sama, berpikir kritis, termotivasi, bertanggung jawab terhadap kelompok. Siswa memiliki kemampuan untuk membantu teman dan terhadap diri sendiri dalam mengikuti kuis nantinya guna mencapai suatu tujuan yaitu mendapatkan penghargaan tim yang super. Adanya evaluasi, siswa mampu merangkum pelajaran yang diterima dari penjelasan guru maupun hasil kerja kelompok yang dilakukan. Guru mengevaluasi hasil belajar tentang materi yang telah dipelajari dimana siswa tidak diperbolehkan bekerja sama.

\section{c. Kelemahan STAD (Student Team Achievement Division)}

a) Karena tidak adanya kompetisi diantara anggota masing-masing kelompok, anak yang berprestasi bisa saja menurunsemangatnya.

b) Jika guru tidak bisa mengarahkan anak, maka anak yang berprestasi bisa jadi lebih dominan dan tidak terkendali (Kurniasih, 2016:23).

\section{d. Langkah-langkah Model Pembelajaran STAD (Student Team Achievement Division)}

Menurut Rusman (Komang et al., 2017), langkah-langkah pembelajaran model student teams achievement division (STAD) adalah sebagai berikut:

1) Penyampaian tujuan dan motivasi. Menyampaikan tujuan pelajaran yang ingin dicapai pada pembelajaran tersebut dan memotivasi siswa untuk belajar.

2) Pembagian kelompok. Siswa dibagi ke dalam beberapa kelompok, dimana setiap kelompoknya terdiri dari 4-5 siswa yang memprioritaskan heterogenitas (keragaman) kelas dalam prestasi akademik, gender/jenis kelamin, rasa atau etnik.

3) Presentasi dari guru. Guru menyampaikan materi pelajaran dengan terlebih dahulu menjelaskan tujuan pelajaran yang ingin dicapai pada pertemuan tersebut serta pentingnya pokok bahasan tersebut dipelajari. Guru memberi motivasi siswa agar dapat belajar dengan aktif dan kreatif. Di dalam proses pembelajaran guru dibantu oleh media, demonstrasi, pertanyaan atau masalah nyata yang terjadi dalam kehidupan sehari-hari. Dijelaskan juga tentang ketrampilan dan kemampuan yang 
diharapkan dikuasai siswa, tugas dan pekerjaan yang harus dilakukan serta caracara mengerjakannya.

4) Kegiatan belajar dalam tim (kerja tim). Siswa belajar dalam kelompok yang telah dibentuk. Guru menyiapkan lembaran kerja sebagai pedoman bagi kerja kelompok, sehingga semua anggota menguasai dan masing-masing memberikan kontribusi. Selama tim bekerja, guru melakukan pengamatan, memberikan bimbingan, dorongan dan bantuan bila diperlukan. Kerja tim ini merupakan ciri terpenting dari STAD.

5) Kuis (evaluasi). Guru mengevaluasi hasil belajar melalui pemberian kuis tentang materi yang dipelajari dan juga melakukan penilaian terhadap presentasi hasil kerja masing-masing kelompok. Siswa diberikan kursi secara individual dan tidak dibenarkan bekerja sama. Ini dilakukan untuk menjamin agar siswa secara individu bertanggung jawab kepada diri sendiri dalam memahami bahan ajar tersebut. Guru menetapkan skor batas penguasaan untuk setiap soal, misalnya 60, 75, 84, dan seterusnya sesuai dengan tingkat kesulitan siswa.

6) Penghargaan prestasi tim. Setelah pelaksanaan kuis, guru memeriksa hasil kerja siswa dan diberikan angka dengan rentang 0-100.

\section{e. Model Pembelajaran Coooperative Learning tipe STAD (Student team Achievement Divisions) Terhadap Pemahaman Konsep}

Model pembelajaran sangat berpengaruh untuk meningkatkan pemahaman konsep peserta didik. Penulis menyatakan bahwa model pembelajaran cooperative learning tipe STAD merupakan salah satu bagian dari proses pembelajaran yang dapat meningkatkan pemahaman konsep peserta didik dimana karakteritik soal-soal pemahaman sangat mudah dikenal. Misalnya dengan mengungkapkan tema, topik, atau masalah yang sama dengan yang pernah di pelajari atau diajarkan, tetapi materinya, berbeda. Mengungkapkan tentang sesuatu dengan bahasa sendiri dengan simbol tertentu termasuk ke dalam pemahaman terjemahan. Dapat menghubungkan hubungan antar unsur dari keseluruhan pesan suatu karangan termasuk ke dalam pemahaman penafsiran.

Jadi dapat ditarik kesimpulan ada keterkaitan antara model pembelajaran STAD dengan pemahaman konsep dimana kegiatan proses belajar dengan menggunakan model pembelajaran STAD ada tahap menyampaikan informasi. Berdasarkan pada hal yang telah dikemukakan sebelumnya disimpulkan pula bahwa model STAD dapat meningkatkan pemahaman konsep siswa. Bila model STAD diterapkan sebagaimana mestinya akan dapat meningkatkan pemahaman konsep siswa. 


\section{Pemahaman Konsep}

\section{a. Pengertian Pemahaman Konsep}

Pemahaman Konsep merupakan terjemahan dari istilah understanding yang diartikan sebagai penyerapan arti suatu materi yang dipelajari. Dalam Kamus Besar Bahasa Indonesia (KBBI), pemahaman berasal dari kata "paham" yang berarti menjadi benar. Jika seseorang mengerti dan mampu menjelaskan sesuatu dengan benar, maka orang tersebut dapat dikatakan paham atau memahami. Bloom dalam Yunus (2009) Menyatakan "Pemahaman adalah suatu kemampuan untuk menyerap arti dari materi atau bahan yang dipelajari. Pemahaman merupakan jenjang kognitif C2 yang dalam bahasa disebut Comprehension".

Dari penjelasan diatas dapat disimpulkan bahwa pemahaman merupakan hasil proses belajar mengajar yang ditandai kemampuan menjelaskan atau mendefinisikan suatu informasi dengan kata-kata sendiri. Pemahaman merupakan kemampuan untuk menerangkan dan menginterprestasikan sesuatu. Pemahaman bukan sekedar mengetahui, yang biasanya hanya sebatas mengingat kembali pengalaman dan memproduksi apa yang pernah dipelajari. Pemahaman lebih dari sekedar mengetahui, karena pemahaman melibatkan proses mental yang dinamis. Pemahaman merupakan suatu proses bertahap yang mempunyai kemampuan tersendiri seperti menerjemahkan, menginterprestasi, eksplorasi, aplikasi, analisis, sintesis, dan evaluasi.

\section{b. Tujuan Pemahaman Konsep}

Pemahaman konsep merupakan kegiatan yang satu tingkat lebih tinggi dari hafalan. Pemahaman memerlukan kemampuan menangkap makna atau arti dari suatu konsep. Untuk itu, maka diperlukan adanya hubungan atau pertautan antara konsep makna atau arti dari suatu konsep. Sehingga, tujuan dari adanya pemahaman konsep adalah agar dapat meningkatkan prestasi siswa dalam pembelajaran, serta dapat membentuk pola piker siswa dalam memahami sesuatu, dan bukan hanya sekedar menghafal. Karena jika hanya menghafal tanpa mengetahui maknanya akan hilang begitu saja, sedangkan jika siswa paham beserta konsepnya akan dapat diingat terus untuk kemudian diaplikasikan.

\section{c. Indikator Pemahaman Konsep}

Adapun indikator pemahaman konsep menurut Badan Standar Nasional Pendidikan (2006,), adalah:
a) Menyatakan ulang suatu konsep;
b) Mengklarifikasikan objek-objek menurut sifat-sifat tertentu;
c) Memberi contoh dan non-contoh dari konsep; 
d) Menyajikan konsep dalam berbagai bentuk representasi;

e) Mengembangkan syarat perlu dan syarat cukup suatu konsep;

f) Menggunakan, memanfaatkan, dan memilih prosedur atau operasi tertentu, dan

g) Mengaplikasikan konsep atau pemecahan masalah.

\section{d. Jenis-jenis Pemahaman}

Pemahaman dapat dibedakan ke dalam tiga kategori (Nana Sudjana, 2016) yaitu: Tingkat terendah adalah pemahaman terjemahan, mulai dari terjemahan dalam arti yang sebenarnya, misalnya dari Bahasa Inggris ke dalam Bahasa Indonesia, mengartikan Bhineka Tunggal Ika, mengartikan Merah Putih, menerapkan prinsip-prinsip listrik dalam memasang sakelar. Tingkat kedua adalah pemahaman penafsiran, yakni menghubungkan bagian-bagian terdahulu dengan yang diketahui berikutnya, atau menghubungkan beberapa bagian dari grafik dengan kejadian, membedakan yang pokok dan mana yang bukan pokok. Menghubungkan pengetahuan tentang konjungsi kata kerja subjek, dan possessive pronoun sehingga tahu menyusun kalimat "My friend is studying" bukan "My friend studying" merupakan contoh pemahaman penafsiran. Tingkat ketiga atau tingkat tertinggi adalah pemahaman ekstrapolasi. Dengan ekstrapolasi diharapkan seseorang mampu melihat di balik yang tertulis, dapat membuat ramalan tentang konsekuensi atau dapat memperluas persepsi dalam arti waktu, dimensi, kasus, atau masalahnya.

\section{e. Langkah-langkah Pemahaman Konsep}

Eko Putro (2016), mengatakan "Proses kognitif dalam kategori memahami meliputi menafsirkan, mencontohkan, mengklasifikasikan, merangkum, menyimpulkan, membandingkan dan menjelaskan.

1) Menafsirkan

Menafsirkan terjadi ketika siswa dapat mengubah informasi dari satu bentuk ke bentuk lain. Menafsirkan berupa pengubahan kata-kata menjadi kata-kata lain, gambar dari kata-kata, kata-kata jadi gambar, angka jadi kata-kata, kata-kata jadi angka dan semacamnya. Nama lain menafsirkan adalah menerjemahkan, memparafrasakan, menggambarkan, dan mengklarifikasi.

2) Mencontohkan

Mencontohkan terjadi manakala siswa memberi contoh tentang konsep atau prinsip umum. Mencontohkan melibatkan proses identifikasi ciri-ciri pokok dari konsep atau prinsip-prinsip umum. Nama lain mencontohkan adalah mengilustrasikan dan memberi contoh. 


\section{3) Mengklasifikasikan}

Proses kognitif mengklasifikasikan terjadi ketika siswa mengetahui bahwa sesuatu (misalnya, suatu contoh) termasuk dalam kategori tertentu (misalnya, konsep atau prinsip). Mengklasifikasikan melibatkan proses mendeteksi ciri-ciri atau polapola yang sesuai dengan contoh dan konsep atau prinsip tersebut. Mengklasifikasikan adalah proses kognitif yang melengkapi proses mencontohkan. Jika mencontohkan dimulai dengan konsep atau prinsip umum dan mengharuskan siswa menemukan contoh tertentu, mengklasifikasikan dimulai dengan contoh tertentu dan mengharuskan siswa menemukan konsep atau prinsip umum. Nama lain dari mengklasifikasikan adalah mengategorikan dan mengelompokkan.

4) Merangkum

Proses kognitif merangkum terjadi ketika siswa mengemukakan satu kalimat yang merepresentasikan informasi yang diterima atau mengabstraksikan sebuah tema. Merangkum melibatkan proses membuat ringkasan informasi, misalnya makna suatu adegan drama, dan proses mengabstraksikan ringkasannya, misalnya menentukan tema atau poin-poin pokoknya. Nama-nama lain untuk merangkum adalah menggeneralisasikan dan mengabstraksi.

5) Menyimpulkan

Proses kognitif menyimpulkan menyertakan proses menemukan pola dalam sejumlah contoh. Menyimpulkan terjadi ketika siswa dapat mengabstraksikan sebuah konsep atau prinsip yang menerangkan contoh-contoh tersebut dengan mencermati ciriciri setiap contohnya dan menarik hubungan di antara ciri-ciri tersebut. Proses menyimpulkan melibatkan proses kognitif dan membandingkan seluruh contohnya. Nama-nama lain dari menyimpulkan adalah mengekstrapolasi, menginterpolasi, dan memprediksi.

6) Membandingkan

Proses kognitif membandingkan melibatkan proses mendeteksi persamaan dan perbedaan antara dua atau lebih objek, peristiwa, ide, masalah, atau situasi. Membandingkan juga melibatkan proses menentukan keterkaitan antara dua atau lebih objek, peristiwa, atau ide yang disuguhkan. Nama lainnya adalah mengontraskan, memetakan, dan mencocokkan.

7) Menjelaskan

Proses kognitif menjelaskan berlangsung ketika siswa dapat membuat dan menggunakan model sebab-akibat dalam sebuah sistem. Model ini dapat diturunkan dari teori atau didasarkan pada hasil penelitian atau pengalaman. 


\section{Penerapan Keterampilan Menulis Teks Prosedur Kompleks Melalui Model Pembelajaran STAD (Student Team Achievement Division)}

Keterampilan berbahasa yang memerlukan tingkat penguasaan yang tinggi adalah keterampilan menulis. Menulis merupakan suatu proses yang kreatif (Semi, 2007). Sebagai suatu proses yang kreatif, menulis harus mengalami suatu proses yang secara sadar bila dilihat hubungan satu dengan yang lain, sehingga berakhir pada satu tujuan yang jelas. Demikian pula dengan kegiatan menulis siswa di sekolah. Melalui kegiatan menulis, siswa akan berusaha berpikir dan mengembangkan imajinasinya. Untuk dapat terampil menulis, khususnya menulis teks prosedur kompleks, tentu siswa harus menguasai kosakata sesuai dengan tema yang disajikan. Dengan menguasai kosakata sesuai dengan tema, maka siswa akan terampil menulis teks prosedur kompleks.

Penggunaan kosakata yang tepat akan menghasilkan teks yang menarik untuk dibaca/d idengar. Sebaliknya, jika penggunaan kosakata tidak tepat, tulisan akan membingungkan pembaca. Dengan kata lain, keterampilan dalam menulis teks prosedur kompleks tergantung kepada kepiawaian penulis dalam mendayagunakan kata-kata yang dikuasainya. Penerapan model pembelajaran kooperatif tipe STAD diharapkan mampu meningkatkan hasil belajar siswa. Keunggulan pembelajaran kooperatif tipe STAD yaitu siswa bekerja dalam kelompok sehingga siswa dapat memahami. konsep materi yang ada dengan bantuan teman kelompok mereka (Ika et al., 2017).

Menurut Slavin, (Ramafrizal, 2018:143) penerapan metode STAD terdiri dari lima komponen utama pembelajaran yang membawa peserta didik pada suasana kerja sama yaitu sebagai berikut:

1) Presentasi Kelas

Presentasi merupakan salah satu jenis pengajaran dalam kelas. Presentasi merupakan komunikasai satu arah, dimana informasi disampaikan kepada audiens oleh pembicara.

2) Kerja Kelempok (tim)

Kerja kelompok atau belajar kelompok merupakan salah satu kegiatan dalam belajar yang dilakukan bersama-sama dengan masing-masing tugas-tugas. Tugas anggota kelompok adalah menguasai materi yang diberikan guru dan membantu teman satu kelempok untuk menguasai materi tersebut. Siswa diberi lembar kegiatan yang dapat digunakan untuk melatih keterampilan yang sedang diajarkan untuk mengevaluasi diri mereka dan teman satu kelompok.

3) Kuis 
Kuis dikerjakan siswa secara mandiri. Tujuannya untuk menunjukkan apa saja yang telah diperoleh siswa selama belajar dalam kelompok. Hasil kuis digunakan sebagai nilaiperkembangan individu dan disumbangkan dalam nilai kelompok.

4) Skor Kemajuan individu

Merupakan nilai dari hasil-hasil kuis yang diadakan dalam belajar kelempok atau tes cepat setelah guru menjelaskan suatu materi. Hasil-hasil nilai tsb bisa menambah nilai secara pribadi yang nantinya dapat memberikan kontribusi poin yang maksimal kepada tim nya dalam sistem skor ini.

5) Rekognisi tim

Pemberian penghargaan kelompok (tim) berdasarkan pada rata-rata nilai perkembangan individu. Diambil dari nilai hasil individu yang dikelompokan dengan hasil kerja kelompok maka akan didapat nilai kelompok sehingga bisa diberikan sebuah penghargaan kelompok terbaik. Tim akan mendapatkan sertifikat atau bentuk penghargaan yang lain apabila skor rata-rata mereka mencapai kriteria tertentu.

\section{B. Penelitian yang Relevan}

Penelitian yang relevan dengan penelitian ini di antaranya adalah sebagai berikut:

Pertama, penelitian dengan judul "Pengaruh Penggunaan Model Student Team Achievement Divion (STAD) terhadap Kemampuan Menulis Teks Prosedur Kompleks Pada Siswa Kelas X Akuntansi II SMK Negeri 1 Kota Jambi Tahun Ajaran 2017/2018” (Suratmi \& Gafar, 2017). Hasil penelitian ini dilakukan di SMK Negeri 1 Kota Jambi di kelas X AK 2 yang berumlah 36 orang siswa. Pada proses pembelajaran, dilakukan pretes dan posttest. Pretes dilakukan sebelum materi diberikan dengan untuk mengetahui kemamuan awal siswa tentang materi teks prosedir kompleks. Postes dilakukan setelah materi disampaikan. Dalam penelitian ini penulis menggunakan model pembalajaran Student Team Achievemnt Division (STAD).nilai tertinggi postes setelah pembelajaran menngunakn model STAD adalah 97 lebih besar dari nilai tertinggi yang didapat pada saat pretes sebesar 91. Nilai terendah yang didapat pada saat postes adalah 80 lebih tinggi dari nilai terendah yang didapat pada saat pretes sebesar 63. Nilai simpangan baku pada postes lebih kecil dari nilai simpangan baku pada saat pretes, artinya rentang nilai tertinggi dan terendah pada saat postes tidak terlalu jauh dengan nilai simpangan baku postes 5,222 sedangkan simpangan baku pre-tes 8,412. Selain itu dari nilai rata-ratajuga menunjukkan model pembelajaran STAD memberikan pengaruh yang baik terhadap kemampuan menulis teks prosedur kompleks. Nilai rata-rata postes lebih baik dari pretes dengan nilai rata-rata postes sebesar 88,36 sedangkan nilai ratarata pretes hanya sebesar 77,75 . 
Kedua,penelitian dengan judul "Peningkatan Keterampilan Menulis Karangan dengan Model Pembelajaran Kooperatif Tipe STAD Pada Siswa Kelas III SDN 3 Ngargosari Tahun 2011/2012" (Mulyanto \& Kuswadi, 2011). Hasil penelitian berdasarkan pengamatan, siswa cukup aktif memperhatikan penjelasan guru. Selama pelaksanaan pembelajaran, guru memberikan informasi secara cermat, memberi motivasi, dan melaksanakan penilaian dengan teliti. Prestasi kegiatan siswa dalam pelaksanaan pembelajaran siklus II pertemuan ke-1 mencapai rata-rata 85.00 dari 14 siswa, dan siswa yang memperoleh nilai $\geq 65$ sebanyak 12 siswa atau 85,71 \% dari 14 siswa. Pembelajaran dikatakan berhasil apabila nilai rata-rata kelas mencapai 6,5 dan siswa yang mendapat nilai $\geq 6,5$ sebanyak $85,71 \%$. Dengan demikian nilai rata-rata kelas yang mencapai rata-rata 74,42 dan siswa yang memperoleh nilai $\geq 6,5$ sebanyak 12 siswa atau 85,71 dari 14 siswa, menunjukkan bahwa keterampilan manulis karangan melalui model pembelajaran kooperatif dinyatakan meningkat.

Ketiga, penelitian dengan judul "Peningkatan Keterampilan Menulis Karangan Narasi Melalui Pembelajaran Kooperatif Tipe STAD Pada Siswa Kelas V SDNegeri 1Kejawar Banyumas Jawa Tengah" (Irmasari \& Enny, 2014)). Pembelajaran pada siklus I dilakukan dengan $3 \mathrm{x}$ pertemuan. Pada pertemuan pertama, siswa belajar tentang langkah-langkah menulis karangan narasi, yaitu cara menentukan tema dan menyusun kerangka karangan. Pada pertemuan kedua, siswa belajar tentang struktur kalimat dan pilihan kata (diksi), sedangkan pada pertemuan ketiga siswa belajar tentang ejaan danpenggunaan tanda baca. Pada pertemuan ketiga ini, siswa dites untuk menulis karangan narasi secara individu. Hasilnya, rata-rata nilai menulis karangan narasi kelas menjadi 67,97 pada siklus I. Nilai ratarata tersebut meningkat dari kegiatan pra siklus, tetapi masih dibawah KKM yaitu $\leq 70$. Pembelajaran pada siklus II dilakukan dengan 2x pertemuan. Pada pertemuan pertama, siswa belajar lebih lanjut tentang langkah-langkah cara menulis karangan yang baik dan benar. Pada pertemuan kedua, siswa belajar tentang fungsi huruf kapital dan tanda baca. Aspek tersebut merupakan analisis dari hasil nilai pada siklus sebelumnya antara lain dalam pengembangan isi, tanda baca, dan penggunaan huruf kapital dan tanda baca.Pada pertemuan kedua ini, siswa dites untuk menulis karangan narasi secaraindividu. Hasilnya, rata-rata nilai menulis karangan narasi kelas menjadi74,91 pada siklus II. Nilai rata-rata tersebut meningkat dari kegiatan siklus Idan sudah mencapai $\mathrm{KKM}$ yaitu $\leq 70$. Berdasarkan data nilai rata-rata menulis karangan narasi siswa yang meningkat dari pra siklus, siklus I, dan siklus II, maka dapat dilihat bahwa melalui pembelajaran kooperatif tipe STAD dapat meningkatkan keterampilan menulis karangan narasi siswa.

Persamaan dari ketiga penelitian relevan tersebut adalah sama-sama menggunakan 
model pembelajaran STAD (Student Team Achievement Division)begitu pula dengan penulis yang menggunakan model pembelajaran STAD dalam penelitiannya, kemudian persamaan lainnya adalah pada penelitian relevan yang kedua dan ketiga lokasi penelitiannya samasama di SDN. Sedangkan perbedaannya terletak pada penelitian relevan yang pertama itu tempat penelitiannya adalah di SMK. Dari beberapa penelitian yang telah dilakukan terlihat bahwa model pembelajaran STAD dapat diterapkan dan dapat meningkatkan belajar siswa. Dengan alasan tersebut penulis ingin mencoba model ini pada materi menulis teks prosedur kompleks.

\section{Kerangka Berpikir}

Rully Indrawan (2016) mengatakan, "Kerangka pemikiran (logical construct) adalah upaya menduduk perkarakan seperangkat variabel penelitian di dalam sistematis berpikir peneliti dengan mengacu pada dua landasan pokok, yakni landasan empirikal, dan landasan teoretikal". Pendidikan merupakan suatu aspek pembelajaran diharapkan peserta didik mampu berpartisipasi dalam pemikirannya untuk membangun pendidikan kepada keadaan yang lebih baik. Berkaitan dengan hal tersebut peserta didik diharapkan mampu mengasah kemampuannya sendiri dalam menyikapi fenomena yang ada. Dalam menyikapi fenomena tersebut, guru harus memperhatikan peserta didik dalam memahami sekaligus mendalami suatu kejadian termasuk dalam pemahaman konsep, yang akan diterapkan pada kelas, dimana kelompok akan dibagi secara merata menurut ras, jenis kelamin, etnis dan suku.

Ketika menyelesaikan tugas kelompok, setiap peserta didik dalam sebuah kelompok belajar dituntut untuk saling bekerja sama dan saling membantu untuk memahami materi pelajaran. Belajar kelompok memungkinkan peserta didik selalu terlibat aktif dalam proses belajar mengajar karena peserta didik mempunyai tanggung jawab belajar yang lebih besar sehingga memungkinkan meningkatnya pemahaman konsep pada ketreampilan menulis teks prosedur. Guru berperan sebagai organisator, motivator dan salah satu sumber informasi selama kegiatan belajar kelompok berlangsung. Model pembelajaran yang sudah dikembangkan adalah model pembelajaran kooperatif tipe Student Teams Achievement Division (STAD).

Jenis pemahaman dapat dibedakan kedalam tiga kategori yaitu tingkat terendah adalah pemahaman terjemahan, tingkat kedua adalah pemahaman penafsiran dan tingkat ketiga atau tingkat tertinggi adalah pemahaman ekstrapolasi (Sudjana, 2017). Peserta didik dapat dikatakan memahami konsep teks prosedur apabila peserta didik dapat menerjemahkan arti dari pengertian teks prosedur, struktuk teks prosedur, kaidah kebahasaan teks prosedur, penilaian dakam menulis teks prosedur, dan lain-lain. Penelitian ini dilakukan untuk 
menengetahui penerapan keterampilan menulis teks prosedur melalui model pembelajaran STAD pada siswa kelas X SMAN 1 Nan Sabaris. Adapun alur kerangka berpikir penulis, yaitu:

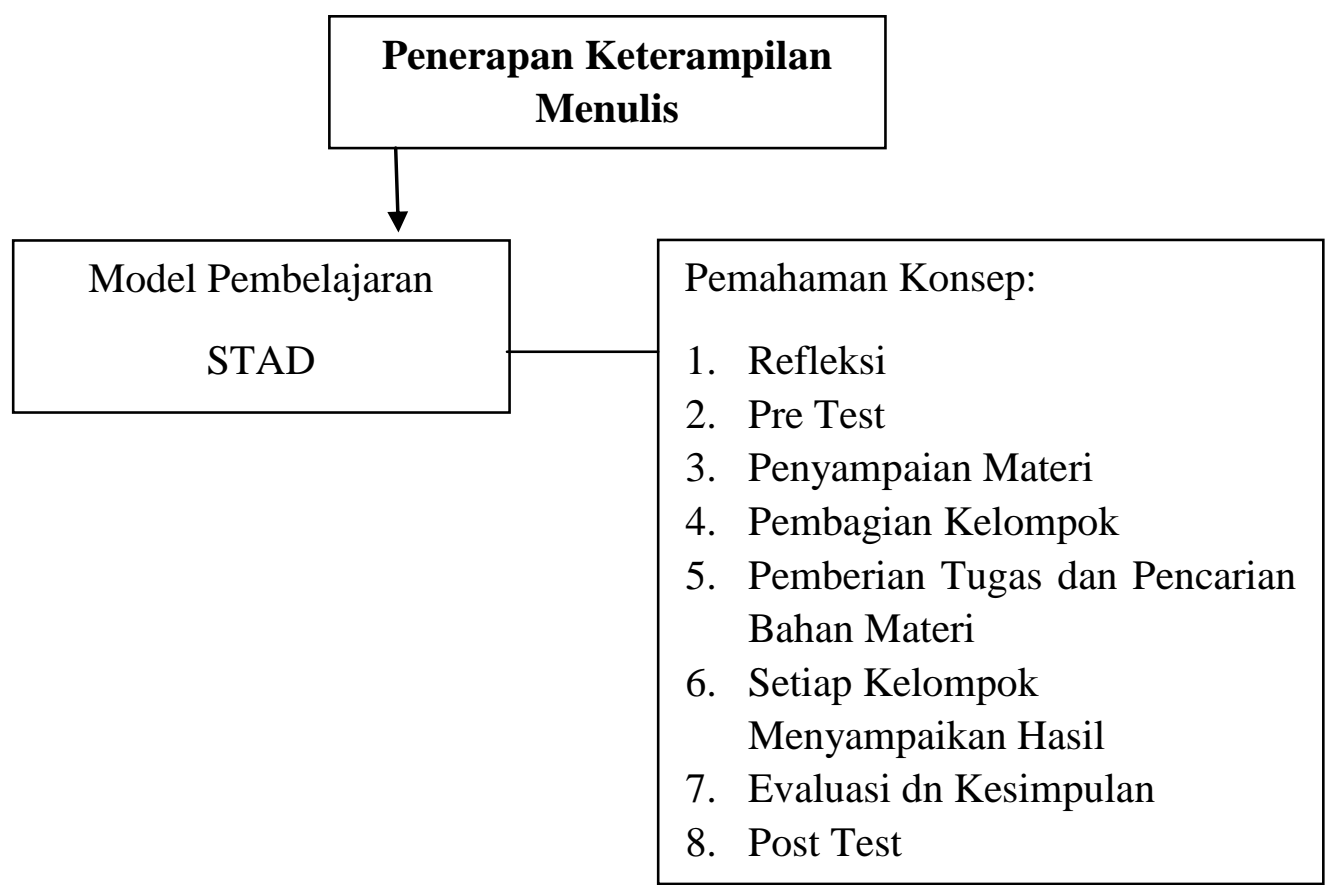

\section{Gambar 1.1 Kerangka Berpikir}

\section{Hipotesis Penelitian}

Menurut Sugiyono (2015:96), "Hipotesis adalah jawaban sementara terhadap rumusan masalah penelitian kajian dinyatakan dalam bentuk kalimat pernyataan". Hipotesis merupakan jawaban sementara yang masih perlu diuji kebenarannya. Berdasarkan kajian teori dan kerangka berpikir tersebut diatas dapat dirumuskan hipotesis bahwa "Terjadi Penerapan Keterampilan Menulis Teks Prosedur Kompleks Melalui Model Pembelajaran STAD (Student Team Achievement Division) Pada Siswa Kelas X SMAN 1 Nan Sabaris". 


\section{BAB III \\ METODOLOGI PENELITIAN}

\section{A. Jenis Penelitian}

Jenis penelitian ini merupakan penelitian kualitatif. Bogdan dan Taylor (Moleong, 2012:4) mengatakan bahwa penelitian kualitatif adalah prosedur penelitian yang menghasilkan data deskriptif yang berupa kata-kata tertulis atau lisan dari orang-orang dan perilaku yang dapat diamati. Penelitian ini merupakan penelitian yang didasarkan pada data alamiah yang berupa kata-kata dalam mendeskripsikan objek yang diteliti. Menurut Koentjaraningrat (1993:89) penelitian kualitatif adalah desain penelitian yang memiliki tiga format, ketiga format tersebut meliputi penelitian deskriptif, dan verifikasi.

\section{B. Metode Penelitian}

Metode penelitian yang digunakan pada penelitian ini adalah metode penelitian deskriptif. Metode deskriptif bertujuan untuk mendeskripsikan atau memaparkan peristiwa yang sedang terjadi pada masa kini (lbnu et al., 2003). Selanjutnya, Mardalis (2009) menjelaskan bahwa metode penelitian deskriptif merupakan metode penelitian yang bertujuan untuk mendeskripsikan apa-apa yang sedang berlaku. Jadi, di dalamnya terdapat upaya-upaya untuk mendeskripsikan, mencatat, menganalisis, dan menginterprestasikan kondisi-kondisi yang sedang terjadi. Metode deskriptif digunakan untuk melihat, mendeskripsikan, dan menganalisis data yang berkaitan dengan penerapan keterampilam menulis teks prosedur kompleks melalui model pembelajaran STAD (Student Team Achievement Division) pada siswa kelas X SMAN 1 Nan Sabaris. Menurut Moleong (2010) tujuan penelitian deskriptif adalah untuk memahami fenomena tentang apa yang dialami oleh subjek penelitian.

\section{Data dan Sumber Data}

\section{Data}

Data dalam penelitian ini adalah hasil pengumpulan data mengenai penerapan pembelajaran STAD (Student Team Achievement Division) dalam pembelajaran teks prosedur kompleks pada siswa kelas X SMAN 1 Nan Sabaris yang dilakukan guru bahasa Indonesia di SMAN 1 Nan Sabaris yang diperoleh dari sumber data.

\section{Sumber Data}


Sumber data dalam penelitian ini adalah dokumentasi yang disimpan guru dalam bentuk tulisan teks prosedur kompleks siswa kelas X SMAN 1 Nan Sabaris. Data diperoleh dengan cara meminta arsipan tugas menulis teks prosedur kompleks siswa kepada guru mata pelajaran Bahasa Indonesia kelas X SMAN 1 Nan Sabaris.

Menurut Lofland (Moleong, 2013: 157) "Sumber data utama dalam penelitian kualitatif adalah kata-kata, dan tindakan, selebihnya adalah tambahan seperti dokumen dan lain-lain”. Sumber data akan diambil dari dokumen, hasil wawancara, catatan lapangan dan hasil dari observasi.

\section{Instrumen Penelitian}

Instrumen penelitian kualitaif adalah peneliti sendiri. Menurut Moleong (2012) penelitian kualitatif, peneliti sendiri atau dengan bantuan orang lain merupakan alat pengumpul data utama. Selain itu, kedudukan peneliti dalam penelitian kualitatif adalah sebagai perencana, pengumpulan data, penganalisisan, penafsir data, dan akhimya menjadi pelapor hasil penelitiannya. Hal ini sesuai dengan pendapat Sugiyono (2010:8) yang menyatakan bahwa instrumen penelitian kualitatif adalah orang atau human instrument, yaitu peneliti sendiri. Berdasarkan pendapat para ahli tersebut dapat disimpulkan bahwa dalam penelitian kualitatif instrumen penelitiannya adalah orang atau peneliti sendiri. Peneliti telah dibekali dengan pengetahuan dan teori yang berkenaan dengan topik penelitiannya. Selain itu, peneliti dibantu oleh instrumen tambahan yaitu pedoman observasi, wawancara dan studi dokumentasi.

\section{E. Teknik Pengumpulan Data}

Teknik pengumpulan data yang digunakan dalam penelitian ini, yaitu observasi, wawancara, dan studi dokumentasi.

1. Observasi

Rubiyanto (2011:85) menyatakan bahwa observasi adalah cara mengumpulkan data dengan jalan mengamati langsung terhadap objek yang di teliti. Peneliti menggunakan observasi non partisipatif yang artinya peneliti hanya melakukan pengamatan biasa (Djam'an dan Aan, 2013). Menurut Arikunto (Imam Gunawan 2013: 143) observasi merupakan suatu teknik pengumpulan data yang dilakukan dengan cara mengadakan peneliti secara teliti, serta pencatatan secara sistematis.

Menurut Rachman (2015: 93) observasi adalah sebagai pengamatan dan pencatatan secara sistematis terhadap gejala yang tampak pada objek peneletian. 
Observasi akan dilakukan oleh peneliti di SMAN 1 Nan Sabaris untuk mengetahui apakah guru sudah menerapkan model pembelajaran STAD pada keterampilan menulis teks prosedur kompleks siswa kelas X, dan untuk mengetahui apakah siswa kelas X sudah terampil dalam menulis teks prosedur kompleks. Pada tahap ini peneliti melakukan observasi di SMAN 1 Nan Sabaris. Observasi diberi kode (O) Untuk mempermudah observasi, peneliti melakukan dimensi indikator observasi.

2. Wawancara

Wawancara adalah percakapan yang memiliki suatu tujuan tertentu oleh dua pihak, yaitu pewawancara dan narasumber yang memberikan jawaban atas pertanyaan yang diajukan oleh pewawancara. Menurut Nasution (Sugiyono 2016:137) wawancara digunakan sebagai teknik pengumpulan data apabila ingin melakukan studi pendahuluan untuk menemukan permasalahan yang harus diteliti, dan juga apabila peneliti ingin mengetahui hal-hal dari responden yang lebih mendalam dan jumlah respondennya sedikit/kecil. Wawancara dilakukan dengan menwawancarai Guru Bahasa Indonesia, dan Siswa Kelas X SMAN 1 Nan Sabaris. Wawancara diberi kode (W).

\section{Studi Dokumentasi}

Studi dokumentasi adalah salah satu metode pengumpulan data kualitatif dengan melihat atau menganalisis dokumen-dokumen yang dibuat oleh subjek sendiri atau orang lain tentang subjek. Studi dokumentasi merupakan salah satu cara yang dapat dilakukan peneliti kualitatif untuk mendapatkan gambaran dari sudut pandang subjek melalui suatu media tertulis dan dokumen lainnya yang ditulis atau dibuat langsung oleh subjek yang bersangkutan. Dokumen yang digunakan dalam penelitian ini adalah dokumen resmi dengan kategori dokumen eksternal. Dokumen eksternal dapat berupa bahan-bahan informasi yang dihasilkan oleh suatu lembaga, seperti majalah, koran, buletin, surat pernyataan, dan lain sebagianya (Bungin, 2010;123).

\section{F. Teknik Pengabsahan Data}

Untuk menilai kualitas data penelitian ini, peneliti menganalisis pengabsahan data. Teknik pengabsahan data yang digunakan dalam penelitian ini adalah teknik triangulasi, yaitu melakulkan pengecekan berdasarkan teori dan penilaian ahli. Teknik triangulasi adalah teknik pemeriksaan keabsahan data dengan memanfaatkan sesuatu di luar data itu, guna keperluan 
pengecekan atau pembanding data (Moleong, 2012). Keabsahan data dilakukan dengan memanfaatkan peneliti atau pengamat lain untuk pengecekan kembali data yang diperoleh. Pemeriksa lain yang mengecek data tersebut adalah guru mata pelajaran Bahasa Indonesia yang mengajar di kelas X SMAN 1 Nan Sabaris. Keabsahan data juga dilakukan dengan pembuktian yang diambil langsung dari teks prosedur kompleks siswa kelas X SMAN 1 Nan Sabaris. Tahap akhir dalam penelitian ini adalah membuat kesimpulan dan menulis laporan.

\section{G. Teknik Penganalisisan Data}

Data penelitian yang sudah diinventarisasi, selanjutnnya dianalisis. Teknik analisis data penelitian ini disesuaikan dengan alur penganalisian data kualitatif. Menurut Sugiyono (2016), alur atau teknik penganalisaan data ada tiga langkah. Langkah-langkah tersebut adalah (1) reduksi data, (2) penyajian data, dan (3) verifikasi data.

Pertama, reduksi data. Mereduksi data merangkum, memilih hal-hal yang pokok, memfokuskan pada hal-hal yang penting, dan membuang hal yang tidak perlu. Reduksi data bisa dilakukan dengan jalan melakukan abstraksi. Abstraksi merupakan usaha membuat rangkuman yang inti, proses dan pernyataan-pernyataan yang perlu dijaga sehingga tetap berada dalam data penelitian. Dengan kata lain proses reduksi data ini dilakukan oleh peneliti secara terus menerus saat melakukan penelitian untuk menghasilkan catatan-catatan inti atau mendeskripsikan dari data yang diperoleh dari hasil penggalian data.

Kedua, penyajian data. Langkah ini dilakukan dengan menyajikan sekumpulan intormasi yang tersusun yang memberi kemungkinan adanya penarikan kesimpulan. Hal ini dilakuken dengan alasan data-data yang diperoleh selama proses penelitian kualitatif biasanya berbentuk naratif, sehingga memerlukan penyederhanaan tanpa mengurangi isi dalam teks. Pada tahap ini peneliti berupaya nmengklasitikasian dan menyajikan data sesuai dengan analisis dan pokok permasalahan yang diawali dengan pengkodean pada setiap subpokok permasalahan pada teks.

Ketiga, veritikasi data. Pada tahap ini peneliti mengutarakan kesimpulan dari data-data yang telah diperoleh. Kegiatan ini berguna untuk mencari makna data yang dikumpulkan dengan mencari hubungan. persamaan, atau perbedaan Penarikan kesimpulan dilakukan dengan cara membandingkan kesesuaian pernyataan dari subjek penelitian dengan makna yang terkandung dengan konsep-konsep dasar dalam penelitian. 


\section{DAFTAR PUSTAKA}

Agustina, Sri., Muslim, A., \& Irianto, S. (2020). Penggunaan Model Pembelajaran STAD Berbantu Media Gambar Untuk Meningkatkan Hasil Belajar Matematika Siswa Kelas

V B SDN 4 Teluk, Bayumas Kabupaten Jawa Tengah. Jurnal Ilmiah DIDAKTIKA, 21(1), 79- 99.

Bungin, Burhan. (2010). Metodologi Penelitian Kualitatif. Jakarta: PT Raja Grafindo Persada.

Eko Putro. (2016). Hasil Pembelajaran Di Sekolah. Yogyakarta: Pustaka Belajar.

Gamarsih, Irmasih. (2014). "Peningkatan Keterampilan Menulis Karangan Narasi Melalui Pembelajaran Kooperatif Tipe STAD Pada Siswa Kelas V SD Negeri 1 Kejawar Banyumas Jawa Tengah”. Skripsi: Universitas Negeri Yogyakarta.

Gunawan, Imam. (2013). Metode Penelitian Kualitatif. Jakarta: PT Bumi Aksara.

Hidayati, P. P. (2009). Menulis Essai dan Pembelajarannya. Bandung: Prema Press.

Ika, W., Banggali, T., Husain, H. (2017). Penerapan Model Pembelajaran Kooperatif Tipe Student Team Achievement Division (STAD) untuk Meningkatkan Hasil Belajar Siswa Kelas XI IPA Avogadro SMA Negeri 2 Pangkajene (Studi pada Materi Asam Basa). Jurnal Chemica. 18(1), 76-84.

Indrawan, Rully. (2016). Metodologi Kualitatif, Kuantitatif, dan Campuran. Surabaya: Refika Aditama.

Isjoni. (2011). Pembelajaran Kooperatif Meningkatkan Kecerdasan Komunikasi Antar Peserta Didik.Yogyakarta: Pustaka Pelajar.

Kemendikbud. (2014). Bahasa Indonesia Ekspresi Diri dan Akademik. Jakarta: Balitbang.

Koentjaraningrat. (1993). Metode-metode Penelitian Masyarakat. Jakarta: Gramedia.

Komang, R. R., Gitakarma, S., \& Ariawan, U. (2017). Penerapan M odel Pembelajaran Kooperatif Tipe STAD Berbantuan Video Animasi Untuk Meningkatkan Hasil Belajar Perakitan Komputer. Jurnal Pendidikan Teknik Elektro Undiksha, 6(3), ISSN 25991531.

Kosasih, E. (2014). Jenis-jenis Teks. Analisis Fungsi, Struktur, dan Kaidah serta Langkah Penulisannya. Bandung: Yrama Widya.

Kurniasih dan Berlin Sani. (2016). Model Pembelajaran Untuk Peningkatan Profesionalitas Guru. Jakarta: Kata Pena.

Mahsun. (2014). Teks dalam Pembelajaran Bahasa Indonesia Kurikulum 2013. Jakarta: PT. Raja Grafindo Persada.

Mardalis. (2009). Metode Penelitian Suatu Pendekatan Proposal. Jakarta: Bumi Aksara.

Mardiyah. (2016). Keterampilan Menulis Bahasa Indonesia Melalui Kemampuan Mengembangkan Struktur Paragraf (Studi pada Mahasiswa Jurusan Matematika 
Semester Genap Angkatan Tahun 2015 Fakultas Tarbiyah IAIN Raden Intan Lampung). Jurnal Pendidikan dan Pembelajaran Dasar, 3(2), 2355-1925.

Moleong, L. J. (2010). Metodologi Penelitian Kualitatif. Bandung: Rema Rosdakarya.

Moleong, L. J. (2013). Metodologi Penelitian Kualitatif. Bandung: Rema Rosdakarya.

Moleong, Lexy. (2012). Metode Penelitian Kualitatif. Bandung: Remaja Rosdakarya.

Mulyanto. (2011). "Peningkatan Keterampilan Menulis Karangan dengan Model

Pembalajaran Kooperatif Tipe STAD Pada Siswa Kelas III SDN 3 Ngargosari Tahun 2 011/2012”. Skripsi: Universitas Sebelah Maret.

Novariana, H., Sumardi, \& Tarjana, S. S. (2018). Senior High School Students' Problems in Writing. 2nd English Language and Literature International Conference (ELLiC), 216219.

Prihaniwati, A., Sutama, \& Darmayanti. (2018). Penerapan Model Pembelajaran Kooperatif Tipe Student Team Achievement Division (STAD) Untuk Meningkatkan Kemampuan Menulis Paragraf Eksposisi Siswa Kelas VIII SMP Mutiara Singaraja. E-Journal Jurusan Pendidikan Bahasa dan Sastra Indonesia, 7(2).

Rababah, L. M., Mohamed, A. H. Bin, Jdaitawi, M. T., \& Melhem, N. Z. B. (2013). The Level of Cretivity in English Writing among Jordanian Secondary School Students. Arts and Design Studies, 10, 25-29.

Rachman, M. (2015). 5 Pendekatan Penelitian: Kuantitatif, Kualitatif, Mixed, PTK, R\&D. Yogyakarta: Magnum Pustaka Utama.

Rakafaeri, Ramadhan, S., \& Basri, I. (2020). The Development of Problem-Based Learning Module for Writing Exposition Paragraphs for X Grade Students of SMA N 8 Padang. Proceedings of the Eighth International Conference on Language and Arts (ICLA2019), $38-42$.

Ramafrizal, Yudho Suryana dan Julia, Teni. S. (2018). Kajian Model Pembelajaran Kooperatif Tipe STAD (Student Teams Achievement Division) Dalam Upaya Meningkatkan Efektivitas Proses Belajar Mengajar Akuntansi. Jurnal Kajian Pendidikan Ekonomi dan Ilmu Ekonomi. 2(2), 2549-2284.

Rojaki. (2012). Upaya Meningkatkan Kemampuan Menulis Puisi Melalui Model Pembelajaran Sinektik Siswa Kelas X 3 SMA Negeri 2 Sekayu. Jurnal llmiah Guru, 2.

Rosidi, I. (2009). Menulis... Siapa Takut? (pp. 2-3). Yogyakarta: Kanisius.

Rubiyanto, Rubino. (2011). Metode Penelitian Pendidikan. Surakarta: UMS Press.

Sardila, V. (2015). Strategi Pengembangan Linguistik Teraan Melalui Kemampuan Menuis Biografi dan Autobiografi: sebuah upaya membangun keterampilan menulis kreatif mahasiswa. An-Nida': Jurnal Pemikiran Islam, 40(2), 110-117. 
Sari, Y., Ramadhan, S., \& Rasyid, Y. (2018). Hubungan Antara Keterampilan Membaca Pemahaman dengan Keterampilan Menulis Teks Laporan Hasil Observasi Siswa Kelas X SMK 3 Padang. Pendidikan Bahasa Dan Sastra Indonesia, 7(3), 446-453.

Satori, Djam'an dan Komariah, Aan. (2013). Metode Penelitian Kualitatif. Bandung: Alfabeta.

Semi, M. A. (2007). Dasar-dasar Keterampilan Menulis. Bandung: Angkasa.

Septia Dewi br. Ginting, Lisa dan Rosmilan Pulungan. (2020). Pembelajaran Kooperatif Tipe STAD Terhadap Keterampilan Menulis Teks Anekdot. Jurnal Penelitian Pendidikan Bahasa dan Sastra, 5(2).

Siti, N, A., Sutama, M., \& Nurjaya, G. (2016). Pembelajaran Menulis Teks Prosedur Berdasarkan Hasil Wawancara di Kelas VIII A1 SMP Negeri 1 Singaraja. E-Journal Pendidikan Bahasa dan Sastra Indonesia Universitas Pendidikan Ganesha Jurusan Pendidikan Bahasa dan Sastra Indonesia, 5(3).

Slavin, Robert E. (2005). Cooperatif Learning. London: Allymand Bacon.

Sudjana, N. (2017). Penilaian Hasil Proses Belajar Mengajar. Bandung: PT. Rosdakarya.

Sugiyono. (2010). Metode Penelitian Kuantitatif dan Kualitatif dan R\&D. Bandung: Alfabeta.

Sugiyono. (2016). Metode Penelitian Kuantitatif, Kualitatif dan R\&D. Bandung: Alfabeta. Suratmi. (2017). "Pengaruh Model Student Team Achievement Division (STAD) terhadap Kemampuan Menulis Teks Prosedur Kompleks Pada Siswa Kelas X Akuntansi II SMK Negeri 1 Kota Jambi Tahun Ajaran 2017/2018”. Skripsi: Universitas Batang Hari Jambi.

Tarigan, H. G. (2015). Berbicara Sebagai Keterampilan Berbahasa (p. 2). Bandung: Angkasa.

Valiantien, N. M., Setyowati, R., \& Ariani, S. (2016). Igniting Students' Motivation in Writing Through Journal Writing. Proceedings of the Fourth International Seminar on English Language and Teaching (ISELT-4), 155-161.

Winarsih, Anis Dwi. (2015). PeningkatanKemampuan Menulis Teks Prosedur Kompleks Melalui Model Pembelajaran STAD (Student Team Achievement Division) Pada Kelas X-IPA 3 SMAN Candipuro Lumajang. Jurnal Inovasi Pembelajaran, 1(2), 122132.

Yuniar. (2018). Meningkatkan Kemampuan Menulis Siswa dengan Menggunakan Model Pembelajaran Tipe Student Teams Achievement Division (STAD). Journal of Education Action Research, 2(1), 67-73. 
